Article

\title{
Cytotoxic and Antioxidant Compounds from the Stem Bark of Goniothalamus tapisoides Mat Salleh
}

\author{
Rosalind Pei Theng Kim ${ }^{1}$, Vicky Bihud ${ }^{2}$, Khalit bin Mohamad ${ }^{3}$, Kok Hoong Leong ${ }^{3}$, \\ Jamaludin bin Mohamad ${ }^{4}$, Fasihuddin bin Ahmad ${ }^{5}$, Hazrina Hazni ${ }^{1}$, Noraini Kasim ${ }^{2}$, \\ Siti Nadiah Abdul Halim ${ }^{1}$ and Khalijah Awang ${ }^{1, *}$
}

1 Department of Chemistry, University of Malaya, 50603 Kuala Lumpur, Malaysia; E-Mails: rosalindkim@hotmail.com (R.P.T.K.); hazrinahazni@um.edu.my (H.H.); nadiahhalim@um.edu.my (S.N.A.H.)

2 Faculty of Applied Sciences, MARA University of Technology, 40450 Shah Alam, Selangor, Malaysia; E-Mails: vicky@salam.uitm.edu.my (V.B.); norainikasim@salamuitm.edu.my (N.K.)

3 Department of Pharmacy, University of Malaya, 50603 Kuala Lumpur, Malaysia; E-Mails: khalitmohamad@um.edu.my (K.M.); leongkh@um.edu.my (K.H.L.)

4 Institute of Biological Sciences, Faculty of Sciences Building, University of Malaya, 50603 Kuala Lumpur, Malaysia; E-Mail: jamal@um.edu.my

5 Faculty of Resource Science and Technology, Universiti Malaysia Sarawak, 94300 Kota Samarahan, Sarawak, Malaysia; E-Mail: bfasih@frst.unimas.my

* Author to whom correspondence should be addressed; E-Mail: khalijah@um.edu.my; Tel.: +603-79674064; Fax: +603-79674193.

Received: 8 November 2012; in revised form: 16 December 2012 / Accepted: 19 December 2012 / Published: 21 December 2012

\begin{abstract}
Eleven compounds: goniomicin A (1), goniomicin B (2), goniomicin C (3), goniomicin D (4), tapisoidin (5), goniothalamin (6), 9-deoxygoniopypyrone (7), pterodondiol (8), liriodenine (9), benzamide (10) and cinnamic acid (11), were isolated from the stem bark of Goniothalamus tapisoides. All compounds were identified by spectroscopic analysis and, for known compounds, by comparison with published data. Goniothalamin (6) exhibited mild cytotoxic activity towards a colon cancer cell line (HT-29), with an $\mathrm{IC}_{50}$ value of $64.17 \pm 5.60 \mu \mathrm{M}$. Goniomicin B (2) give the highest antioxidant activity in the DPPH assay among all compounds tested, with an $\mathrm{IC}_{50}$ of $0.207 \mu \mathrm{M}$.
\end{abstract}


Keywords: Goniothalamus tapisoides; goniomicins A-D; tapisoidin; cytotoxicity; antioxidant activity

\section{Introduction}

The genus Goniothalamus (Annonaceae) comprises about 160 species of shrubs and trees native to tropical and subtropical Asia [1]. Goniothalamus tapisoides Mat Salleh, locally known as "selada" or "semukau", is endemic to Borneo, especially the Southern part of Sarawak. This species is a small tree of about $5 \mathrm{~m}$ in height and is used by the native folks as an abortifacient and to cure poisonous animal bites such as snake, scorpion or insect bites. It is also used to relieve stomachaches [2].

In recent years, Goniothalamus species have been receiving considerable attention because of their reputation for producing styryl lactones and acetogenins which possess remarkable cytotoxic and antitumor properties against various human tumor cell lines such as A-549 (lung carcinoma), HL-60 (promyelocytic leukemia), and SGC-7901 (stomach cancer) [1,3]. Previous studies on the mechanism of action of $(R)$-goniothalamin have shown that it is able to induce apoptosis in MCF-7 (breast cancer) and HL-60 human cancer cells [3-6].

In our continuous effort to search for new and bioactive compounds from the Malaysian flora [7-10], we have embarked on a chemical study of the cytotoxic stem bark extracts of G. tapisoides Mat Salleh. To the knowledge of the authors, such a phytochemical study of this plant has never been reported. From this study, the eleven compounds shown in Figure 1 were isolated, of which five are new: goniomicin A (1), goniomicin B (2), goniomicin C (3), goniomicin D (4) and tapisoidin (5). The known compounds are goniothalamin (6), 9-deoxygoniopypyrone (7), pterodondiol (8), liriodenine (9), benzamide (10) and cinnamic acid (11). Compounds 1-6 were tested for cytotoxic activity against eight cancer cell lines and for antioxidant activity.

Figure 1. Structure of compounds 1-11.<smiles>O=C(O)/C=C\CC(O)/C=C/c1ccccc1</smiles>

1

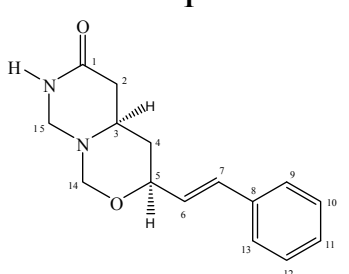

4

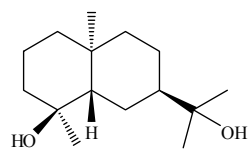

8<smiles>COC(=O)/C=C/CC(O)/C=C/c1ccccc1</smiles>

2<smiles>CN1C(=O)c2cc(O)c(O)c3c2C1Cc1ccccc1-3</smiles>

5

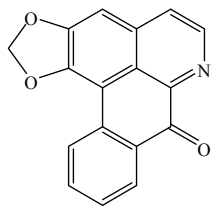

9<smiles>O=C1C[C@H](O)[CH]C[C@H](/C=C/c2ccccc2)O1</smiles>

3
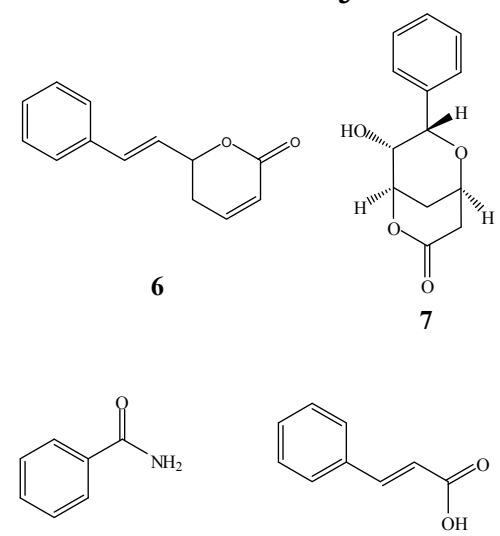

11 


\section{Results and Discussion}

\subsection{Isolation and Chemistry}

Goniomicin A (1) was obtained as a pale yellowish amorphous powder, $[\alpha]_{D}^{26.7}+2.5^{\circ}$ (c 0.0239 , $\mathrm{MeOH}$ ). A molecular formula of $\mathrm{C}_{13} \mathrm{H}_{14} \mathrm{O}_{3}$ was deduced from the ESI-TOF-MS spectrum, that showed a strong fragmentation peak at $m / z 199.1020\left[\mathrm{M}-\mathrm{H}^{-} \mathrm{H}_{2} \mathrm{O}\right]^{-}$(calc. 199.0759) corresponding to the loss of a water molecule, thus indicating the presence of a hydroxyl group. This is in agreement with the ${ }^{13} \mathrm{C}$-NMR and HSQC spectra which confirmed the presence of thirteen carbons. The UV spectrum $\left(\lambda_{\max } 206\right.$ and $251 \mathrm{~nm}$ ) suggested the presence of a phenyl group [11]. The IR spectrum showed absorptions of hydroxyl $\left(v_{\max } 3344 \mathrm{~cm}^{-1}\right)$ and carbonyl $\left(v_{\max } 1668 \mathrm{~cm}^{-1}\right)$ functionalities.

The ${ }^{1} \mathrm{H}-\mathrm{NMR}$ spectrum (Table 1 ) revealed downfield signals at $\delta 5.96, \delta 6.12, \delta 6.20$ and $\delta 6.59$ assignable to H-2, H-3, H-6 and H-7, respectively, therefore indicating the presence of four olefinic protons. The coupling constant between $\mathrm{H}-2$ and $\mathrm{H}-3$ is $11.5 \mathrm{~Hz}$ which is indicative of a cisconfiguration [11]. On the other hand, H-6 and H-7 assumed a trans-configuration, with a $J$ coupling value of $16.0 \mathrm{~Hz}$.

Table 1. ${ }^{1} \mathrm{H}-\mathrm{NMR},{ }^{13} \mathrm{C}-\mathrm{NMR}$ and $\mathrm{HMBC}(400 \mathrm{MHz})$ data of $\mathbf{1}$ and $\mathbf{2}\left(\mathrm{CDCl}_{3}, \delta\right.$ in ppm, $J$ in $\left.\mathrm{Hz}\right)$.

\begin{tabular}{|c|c|c|c|c|c|c|}
\hline \multirow{2}{*}{$\begin{array}{c}\text { Atom } \\
\text { No. }\end{array}$} & \multicolumn{3}{|c|}{1} & \multicolumn{3}{|c|}{2} \\
\hline & $\delta^{13} \mathrm{C}$ & $\delta{ }^{1} \mathbf{H}$ & HMBC & $\delta^{13} \mathrm{C}$ & $\delta^{1} \mathbf{H}$ & HMBC \\
\hline 1 & 169.6 & - & & 166.8 & - & \\
\hline 2 & 125.3 & $5.96(1 \mathrm{H}, d, J=11.5)$ & $\mathrm{C}-1, \mathrm{C}-3, \mathrm{C}-4$ & 123.9 & $5.94(1 \mathrm{H}, d, J=15.6)$ & $\mathrm{C}-1, \mathrm{C}-4$ \\
\hline 3 & 140.6 & $\begin{array}{c}6.12(1 \mathrm{H}, d t \\
J=8.6,11.5)\end{array}$ & C-1, C-4, C-5 & 144.7 & $7.00(1 \mathrm{H}, m)$ & C-1, C-4 \\
\hline $\begin{array}{l}4 \alpha \\
4 \beta\end{array}$ & 36.6 & $\begin{array}{l}2.76(1 \mathrm{H}, m) \\
2.81(1 \mathrm{H}, m)\end{array}$ & $\begin{array}{c}\mathrm{C}-2, \mathrm{C}-3, \mathrm{C}-5, \\
\mathrm{C}-6\end{array}$ & 40.2 & $2.54(2 \mathrm{H}, m)$ & $\begin{array}{c}\mathrm{C}-2, \mathrm{C}-3, \mathrm{C}-5, \\
\mathrm{C}-6\end{array}$ \\
\hline 5 & 71.5 & $4.41(1 \mathrm{H}, m)$ & $\mathrm{C}-3, \mathrm{C}-4, \mathrm{C}-7$ & 71.6 & $\begin{array}{l}4.44(1 \mathrm{H}, d d \\
J=6.6,13.3)\end{array}$ & C-3, C-7 \\
\hline 6 & 131.9 & $\begin{array}{l}6.20(1 \mathrm{H}, d d \\
J=16.0,6.7)\end{array}$ & C-4, C-5, C-8 & 130.9 & $\begin{array}{l}6.22(1 \mathrm{H}, d d, \\
J=16.0,6.6)\end{array}$ & C-5, C-8 \\
\hline 7 & 129.9 & $6.59(1 \mathrm{H}, d, J=16.0)$ & $\begin{array}{c}\text { C-5, C-8, C-9, } \\
\text { C-13 }\end{array}$ & 131.3 & $6.61(1 \mathrm{H}, d, J=16.0)$ & $\begin{array}{l}\text { C-5, C-9, } \\
\text { C-13 }\end{array}$ \\
\hline 8 & 136.7 & - & & 136.3 & - & \\
\hline 9,13 & 126.5 & $7.19-7.34(m)$ & & 126.5 & $7.24-7.38(m)$ & \\
\hline 10,12 & 128.6 & $7.19-7.34(m)$ & $\mathrm{C}-8$ & 128.6 & $7.24-7.38(\mathrm{~m})$ & C-8 \\
\hline 11 & 127.6 & $7.19-7.34(m)$ & & 128.0 & $7.24-7.38(\mathrm{~m})$ & \\
\hline $1-\mathrm{OH}$ & - & $6.27(\mathrm{OH}, b r s)$ & $\mathrm{C}-2$ & - & - & \\
\hline $5-\mathrm{OH}$ & - & $6.57(\mathrm{OH}, b r s)$ & $\mathrm{C}-5$ & - & - & \\
\hline $\begin{array}{c}1- \\
\text { OMe }\end{array}$ & - & - & & 51.6 & $3.72(3 \mathrm{H}, s)$ & $\mathrm{C}-1$ \\
\hline
\end{tabular}

The ${ }^{13} \mathrm{C}$-NMR spectrum (Table 1) showed the presence of one methylene, ten methines, one quaternary carbon and one carbonyl. The carbonyl carbon (C-1) resonated at $\delta 169.6$. The adjacent $\mathrm{C}-2$ and C-3 carbons gave signals at $\delta 125.3$ and $\delta$ 140.6, respectively. The downfield shift of C-3 is due to 
the resonance effect of the $\alpha-\beta$ unsaturated carboxylic acid moiety [11]. In addition, a deshielded oxymethine signal attributable to $\mathrm{C}-5$ was apparent at $\delta 71.5$.

The ${ }^{1} \mathrm{H}-{ }^{1} \mathrm{H}$ COSY spectrum and ${ }^{1} \mathrm{H}^{13} \mathrm{C}$ HSQC spectrum confirmed the connectivities between C-2-C-3-C-4-C-5-C-6-C-7. The HMBC correlations indicated the linkage of the C-2 to carbonyl C-1 and C-7 to the phenyl ring C-8 (Table 1). Thus, the structure of goniomicin A (1) was elucidated as illustrated in Figure 1. The occurrence of compound $\mathbf{1}$ in Goniothalamus tapisoides is of interest since it may be a precursor of goniothalamin (6). A plausible biogenetic pathway for the formation of $\mathbf{6}$ from $\mathbf{1}$ is illustrated in Scheme 1. Compound $\mathbf{1}$ undergoes a dehydration and cyclization reaction to form $\mathbf{6}$.

Scheme 1. Dehydration and cyclization of 1 to 6.
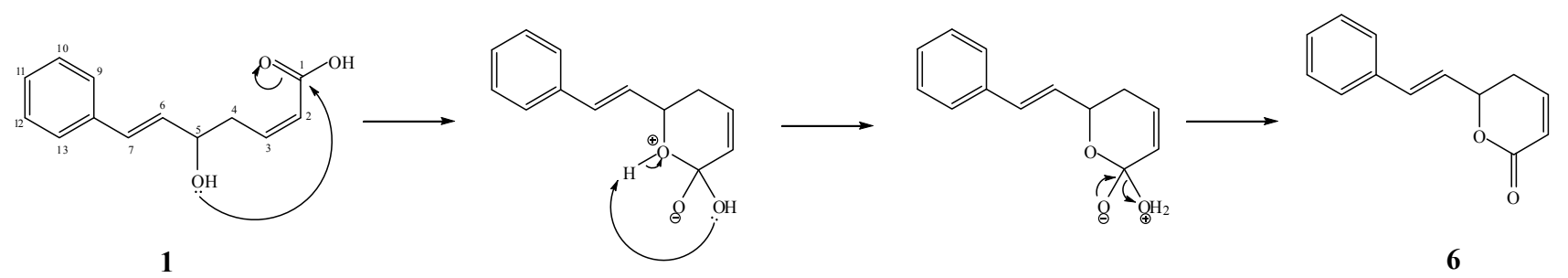

Goniomicin B (2) was isolated as pale yellowish amorphous powder, $[\alpha]_{D}^{26.2}+2.4^{\circ}$ (c 0.0082 , $\mathrm{CH}_{2} \mathrm{Cl}_{2}$ ). Its molecular formula, $\mathrm{C}_{14} \mathrm{H}_{16} \mathrm{O}_{3}$, was deduced from the ESI-TOF-MS $(\mathrm{m} / z$ 231.1201, $[\mathrm{M}-\mathrm{H}]^{-}$; calc. 231.1021). The IR spectrum showed a strong absorption for a conjugated carbonyl group of an ester at $1718 \mathrm{~cm}^{-1}$, while the UV absorption bands at 207 and $251 \mathrm{~nm}$ indicated the presence of a phenyl group [11].

The ${ }^{1} \mathrm{H}-\mathrm{NMR}$ and ${ }^{13} \mathrm{C}-\mathrm{NMR}$ spectra of $\mathbf{1}$ and $\mathbf{2}$ (Table 1 ) are very similar to each other, except for the existence of a three proton singlet at $\delta 3.72$ and a methyl carbon at $\delta 51.6$ in the ${ }^{1} \mathrm{H}-$ and ${ }^{13} \mathrm{C}-\mathrm{NMR}$ spectra, respectively. This observation suggested the presence of an additional methoxyl group, which is attached to the C-1 carbonyl group. A noticeable difference was also observed in the coupling constant value $(15.6 \mathrm{~Hz})$ of protons $\mathrm{H}-2$ and $\mathrm{H}-3$, suggesting a trans-configuration. From the ${ }^{1} \mathrm{H}-\mathrm{NMR}$, ${ }^{13} \mathrm{C}-\mathrm{NMR},{ }^{1} \mathrm{H}-{ }^{1} \mathrm{H}$ COSY, HSQC and HMBC spectra analyses, the complete assignment of goniomicin $\mathrm{B}$ (2) was established.

Goniomicin C (3) was obtained as pale yellowish amorphous powder, $[\alpha]_{D}^{23.5}-4.9^{\circ}$ (c 0.0122 , $\mathrm{CH}_{2} \mathrm{Cl}_{2}$ ). The ESI-TOF-MS spectrum gave a prominent peak at $\mathrm{m} / \mathrm{z}$ 231.1077, [M-H] ; (calc. 231.1021), corresponding to the molecular formula $\mathrm{C}_{14} \mathrm{H}_{16} \mathrm{O}_{3}$. The IR spectrum showed a $\mathrm{C}=\mathrm{O}$ stretching absorption bands at $1731 \mathrm{~cm}^{-1}$ and $\mathrm{C}-\mathrm{O}$ stretching ones at 1241 and $1090 \mathrm{~cm}^{-1}$. The UV absorptions at 206 and $251 \mathrm{~nm}$ suggested the existence of a phenyl group [11].

The ${ }^{1} \mathrm{H}-\mathrm{NMR}$ spectrum of $\mathbf{3}$ is relatively similar to that of goniothalamin (6). However, the olefinic proton signals of the lactone ring are absent. Instead two methylene proton signals and one oxymethine proton signal appeared at $\delta 2.73$ and $\delta 3.82$, corresponding to $\mathrm{H}_{2}-2$ and $\mathrm{H}-3$, respectively. Another oxymethine signal, assignable to $\mathrm{H}-5$, appeared at $\delta 5.20$ as a $d d d$ with coupling constants of 11.0, 6.4 and $3.5 \mathrm{~Hz}$ respectively (Table 2). In addition, one singlet corresponding to three protons of a methoxyl group was apparent at $\delta$ 3.36. The ${ }^{13} \mathrm{C}-\mathrm{NMR}$ spectrum showed the expected fourteen carbons: one methyl, two methylene, nine methines and two quaternary carbons. The oxymethine carbons, C-3 and C-5, resonated at $\delta 71.4$ and $\delta 76.2$, respectively. In the HMBC spectrum (Table 2), 
the carbonyl carbon $(\mathrm{C}-1)$ signal $(\delta 169.7)$ correlated with the protons signal at $\delta 2.73\left(\mathrm{H}_{2}-2\right)$, while the carbon at $\delta 71.4(\mathrm{C}-3)$ correlated with the proton at $\delta 5.20(\mathrm{H}-5)$. Thus it can be deduced that the methoxy group is attached to $\mathrm{C}-3$.

Table 2. ${ }^{1} \mathrm{H}-\mathrm{NMR},{ }^{13} \mathrm{C}-\mathrm{NMR}$ and $\mathrm{HMBC}(400 \mathrm{MHz})$ data of $\mathbf{3}\left(\mathrm{CDCl}_{3}, \delta\right.$ in ppm, $J$ in $\left.\mathrm{Hz}\right)$.

\begin{tabular}{|c|c|c|c|c|c|c|c|}
\hline $\begin{array}{c}\text { Atom } \\
\text { no. }\end{array}$ & $\delta^{13} \mathrm{C}$ & $\delta^{1} \mathbf{H}$ & НМВС & $\begin{array}{c}\text { Atom } \\
\text { no. }\end{array}$ & $\delta^{13} \mathrm{C}$ & $\delta^{1} \mathbf{H}$ & HМBC \\
\hline 1 & 169.7 & - & & 7 & 132.5 & $\begin{array}{c}6.68(1 \mathrm{H}, d, \\
J=16.0)\end{array}$ & $\begin{array}{c}\text { C-5, C-9, } \\
\text { C-13 }\end{array}$ \\
\hline 2 & 35.7 & $\begin{array}{c}2.73(2 \mathrm{H}, t d \\
J=4.3,1.4)\end{array}$ & $\mathrm{C}-1$ & 8 & 136.0 & - & \\
\hline 3 & 71.4 & $3.82(1 \mathrm{H}, m)$ & & 9,13 & 126.7 & $7.24-7.37(\mathrm{~m})$ & \\
\hline $\begin{array}{l}4 \alpha \\
4 \beta\end{array}$ & 33.7 & $\begin{array}{c}1.87(1 \mathrm{H}, d d d, \\
J=14.8,11.0,3.5) \\
2.18(1 \mathrm{H}, m)\end{array}$ & & $\begin{array}{c}10,12 \\
11\end{array}$ & $\begin{array}{l}128.8 \\
128.3\end{array}$ & $\begin{array}{l}7.24-7.37(\mathrm{~m}) \\
7.24-7.37(\mathrm{~m})\end{array}$ & \\
\hline 5 & 76.2 & $\begin{array}{c}5.20(1 \mathrm{H}, d d d, \\
J=11.0,6.4,3.5)\end{array}$ & $\mathrm{C}-3$ & 3-OMe & 56.3 & $3.36(3 \mathrm{H}, s)$ & C-3 \\
\hline 6 & 126.6 & $\begin{array}{l}6.18(1 \mathrm{H}, d d, \\
J=16.0,6.4)\end{array}$ & $\begin{array}{l}\text { C- } 5 \\
\text { C- } 8\end{array}$ & & & & \\
\hline
\end{tabular}

The relative stereochemistry of $\mathbf{3}$ was established by the NOESY spectrum. H-5 $\alpha$, which is axially oriented, correlated with H-4, therefore suggesting that $\mathrm{H}-4$ adopts an $\alpha$ spatial orientation [12]. H-6 showed correlation to $\mathrm{H}-5 \beta$ thus implying that $\mathrm{H}-6$ is $\beta$ oriented.With the aid of the ${ }^{1} \mathrm{H}-\mathrm{NMR}$, ${ }^{13} \mathrm{C}-\mathrm{NMR},{ }^{1} \mathrm{H}-{ }^{1} \mathrm{H}$ COSY, HSQC and HMBC spectra analyses, the full assignment of goniomicin C (3) was determined.

Goniomicin D (4) was crystalised from a solution of hexane-dicholoromethane as white rod crystals (mp. $240-243{ }^{\circ} \mathrm{C}$ ), $[\alpha]_{D}^{23.7}+37.17^{\circ}$ (c $\left.0.0191, \mathrm{MeOH}\right)$. Its molecular formula was determined to be $\mathrm{C}_{15} \mathrm{H}_{18} \mathrm{O}_{2} \mathrm{~N}_{2}$ by ESI-TOF-MS ( $\mathrm{m} / z$ 281.1278, [M+Na] $]^{+}$; calc. 281.1266). The IR spectrum showed absorption peaks of N-H stretching at $3413.15 \mathrm{~cm}^{-1}$ and a $\mathrm{C}=\mathrm{O}$ group at $1662 \mathrm{~cm}^{-1}$ [11]. The UV spectrum revealed maxima at 206 and $252 \mathrm{~nm}$, suggesting the presence of a phenyl group [11].

The ${ }^{1} \mathrm{H}-\mathrm{NMR}$ spectrum showed four methylene signals at $\delta 2.28 / 2.64\left(\mathrm{H}_{2}-2\right), \delta 1.74\left(\mathrm{H}_{2}-4\right), \delta$ 4.13/4.64 $\left(\mathrm{H}_{2}-14\right)$ and $\delta 3.82 / 4.34\left(\mathrm{H}_{2}-15\right)$ (Table 3). The downfield shift of $\mathrm{H}_{2}-14$ and $\mathrm{H}_{2}-15$ were due to the neighboring nitrogen and oxygen. The ${ }^{13} \mathrm{C}$-NMR showed signals corresponding to fifteen carbons: four methylenes, nine methines, one quaternary and one carbonyl carbon. The methylene carbons $\mathrm{C}-14$ and $\mathrm{C}-15$ resonated downfield at $\delta 82.9$ and $\delta 58.9$, respectively. The carbonyl carbon (C-1) gave a peak at $\delta$ 168.9. The HMBC spectrum (Figure 1) revealed cross peaks between the methylene at $\delta 4.13 / 4.64\left(\mathrm{H}_{2}-14\right)$ and $\mathrm{C}-3(\delta 54.1), \mathrm{C}-5(\delta$ 77.3) and $\mathrm{C}-15$ ( $\delta$ 58.9). Two methylene signals of $\mathrm{H}_{2}-2(\delta 2.28 / 2.64)$ and $\mathrm{H}_{2}-15(\delta 3.82 / 4.34)$ were correlated to the carbonyl $\mathrm{C}-1$. From a ${ }^{1} \mathrm{H}-{ }^{1} \mathrm{H}$ COSY experiment, the entire sequence C-2-C-3-C-4-C-5-C-6 was identified. Thorough analyses of 1D and 2D NMR data analyses allowed the full assignment of all protons and carbons as listed in Table 3. 
Table 3. ${ }^{1} \mathrm{H}-\mathrm{NMR},{ }^{13} \mathrm{C}-\mathrm{NMR}$ and $\mathrm{HMBC}(400 \mathrm{MHz})$ data of $4\left(\mathrm{CDCl}_{3}, \delta\right.$ in ppm, $J$ in $\left.\mathrm{Hz}\right)$.

\begin{tabular}{|c|c|c|c|c|c|c|c|}
\hline $\begin{array}{c}\text { Atom } \\
\text { no. }\end{array}$ & $\delta^{13} \mathrm{C}$ & $\delta{ }^{1} \mathbf{H}$ & НМВС & $\begin{array}{c}\text { Atom } \\
\text { no. }\end{array}$ & $\delta^{13} \mathrm{C}$ & $\delta^{1} \mathbf{H}$ & НМВС \\
\hline 1 & 168.9 & - & & 9,13 & 126.6 & $7.19-7.34(\mathrm{~m})$ & \\
\hline $\begin{array}{l}2 \alpha \\
2 \beta\end{array}$ & 37.2 & $\begin{array}{l}2.28(1 \mathrm{H}, d d, \\
J=17.6,7.8) \\
2.64(1 \mathrm{H}, d d, \\
J=17.6,5.5)\end{array}$ & $\begin{array}{c}\text { C-1, C-3, } \\
\text { C-4 } \\
\text { C-1 }\end{array}$ & $\begin{array}{c}10,12 \\
11\end{array}$ & $\begin{array}{l}128.7 \\
128.0\end{array}$ & $\begin{array}{l}7.19-7.34(m) \\
7.19-7.34(m)\end{array}$ & \\
\hline 3 & 54.1 & $2.98(1 \mathrm{H}, m)$ & & $14 \alpha$ & 82.9 & $4.13(1 \mathrm{H}, d, J=9.2)$ & $\begin{array}{c}\mathrm{C}-15, \mathrm{C}-3, \\
\mathrm{C}-5\end{array}$ \\
\hline 4 & 35.6 & $1.74(2 \mathrm{H}, m)$ & $\mathrm{C}-3, \mathrm{C}-5$ & $14 \beta$ & & $4.64(1 \mathrm{H}, d, J=9.2)$ & $\mathrm{C}-3, \mathrm{C}-5$ \\
\hline 5 & 77.3 & $4.17(1 \mathrm{H}, m)$ & & $15 \alpha$ & 58.9 & $3.82(1 \mathrm{H}, d, J=8.7)$ & $\mathrm{C}-1, \mathrm{C}-3$ \\
\hline 6 & 128.3 & $\begin{array}{l}6.20(1 \mathrm{H}, d d, \\
J=16.0,6.0)\end{array}$ & C-5, C-8 & $15 \beta$ & & $\begin{array}{c}4.34(1 \mathrm{H}, d d \\
J=8.7,2.7)\end{array}$ & \\
\hline 7 & 131.3 & $\begin{array}{c}6.63(1 \mathrm{H}, d \\
J=16.0)\end{array}$ & $\begin{array}{c}\text { C-5, C-9, } \\
\text { C-13 }\end{array}$ & $\mathrm{N}-\mathrm{H}$ & - & $6.41(\mathrm{NH}, b r s)$ & \\
\hline 8 & 136.4 & - & & & & & \\
\hline
\end{tabular}

The relative stereochemistry of 4 was established with the aid of the NOESY spectrum. H-15 $\alpha$ which is axially oriented showed a NOESY correlation with H-3, which in turn showed correlation with H-5, therefore suggesting that both H-3 and H-5 assume an $\alpha$-spatial orientation. The structure and relative stereochemistry was further confirmed using single-crystal X-ray diffraction analysis CCDC 912021 contains the supplementary crystallographic data for this paper. These data can be obtained free of charge via www.ccdc.cam.ac.uk/conts/retrieving.html (or from the CCDC, 12 Union Road, Cambridge CB2 1EZ, UK; fax: +44 1223 336033; e-mail: deposit@ccdc.cam.ac.uk). An ORTEP drawing of $\mathbf{4}$ is shown in Figure 2.

Figure 2. HMBC correlations and ORTEP diagram of 4.
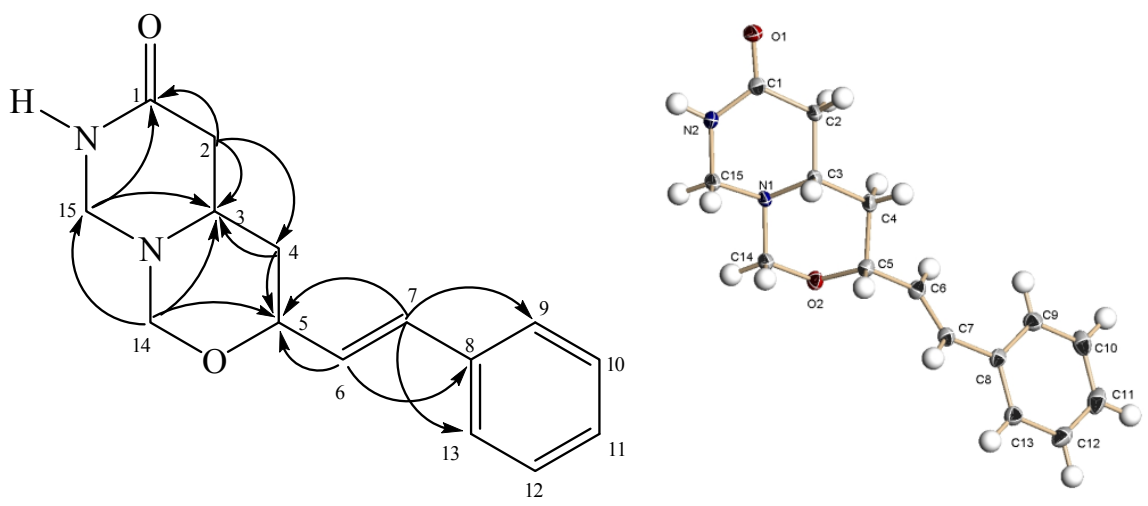

Tapisoidin (5) was obtained as pale yellowish amorphous powder, $[\alpha]_{D}^{23.8}-25.9^{\circ}$ (c 0.0058 , $\left.\mathrm{CH}_{2} \mathrm{Cl}_{2}\right)$. Its molecular formula was determined to be $\mathrm{C}_{18} \mathrm{H}_{17} \mathrm{O}_{4} \mathrm{~N}$ by ESI-TOF-MS $(\mathrm{m} / z$ 334.1074, $[\mathrm{M}+\mathrm{Na}]^{+}$; calc. 334.1055$)$. The IR spectrum displayed a band at $1715 \mathrm{~cm}^{-1}$ representing the $\mathrm{C}=\mathrm{O}$ group of the molecule. The UV spectrum $\left(\lambda_{\max } 209,251,277\right.$ and $\left.322 \mathrm{~nm}\right)$ indicated the presence of a basic aristolactam alkaloid structure [11]. The ${ }^{1} \mathrm{H}-\mathrm{NMR}$ spectrum (Table 4) showed signals for four adjacent aromatic protons at $\delta 8.35(\mathrm{H}-5, d d, J=7.9,1.4), \delta 7.40(\mathrm{H}-6, m), \delta 7.44(\mathrm{H}-7, m)$ and $\delta 7.35$ 
$(\mathrm{H}-8, d d, J=7.9,1.4)$. Signals for three methyl groups at $\delta 3.96, \delta 3.89$ and $\delta 4.00$ were assigned to the methoxyl groups at N-11, C-3 and C-4, respectively. The positions of the methoxyl groups were established from the NOESY and HMBC spectra. In the NOESY spectrum, the methyl protons of the methoxyl group at $\mathrm{C}-3$ showed correlations with $\mathrm{H}-2$. In the HMBC spectrum, the proton signal at $\delta$ $7.23(\mathrm{H}-2)$ correlated with the carbons signal at $\delta 59.7\left(3-\mathrm{OCH}_{3}\right)$ and $\delta 56.0\left(4-\mathrm{OCH}_{3}\right)$, thereby confirmed the assignments of the methoxyl groups.

Table 4. ${ }^{1} \mathrm{H}-\mathrm{NMR},{ }^{13} \mathrm{C}-\mathrm{NMR}$ and $\mathrm{HMBC}(400 \mathrm{MHz})$ data of $5\left(\mathrm{CDCl}_{3}, \delta\right.$ in ppm, $J$ in $\left.\mathrm{Hz}\right)$.

\begin{tabular}{|c|c|c|c|c|c|c|c|}
\hline $\begin{array}{c}\text { Atom } \\
\text { no. }\end{array}$ & $\delta^{13} \mathrm{C}$ & $\boldsymbol{\delta}^{1} \mathbf{H}$ & НМBC & $\begin{array}{c}\text { Atom } \\
\text { no. }\end{array}$ & $\delta^{13} \mathrm{C}$ & $\delta^{1} \mathbf{H}$ & НMBC \\
\hline 1 & 123.1 & - & & $8 \mathrm{a}$ & 131.3 & - & \\
\hline 2 & 105.9 & $7.23(1 \mathrm{H}, s)$ & $\begin{array}{c}\text { C-3, C-4, } \\
\text { C-10a, C-12 }\end{array}$ & $9 \alpha$ & 34.8 & $\begin{array}{c}2.73(1 \mathrm{H}, t \\
J=13.8)\end{array}$ & $\begin{array}{c}\text { C-8a, C-10, } \\
\text { C-10a }\end{array}$ \\
\hline 3 & 150.5 & - & & $9 \beta$ & & $\begin{array}{l}3.49(1 \mathrm{H}, d d \\
J=13.8,6.0)\end{array}$ & C-10a \\
\hline 4 & 155.7 & - & & 10 & 57.3 & $\begin{array}{l}4.60(1 \mathrm{H}, d d, \\
J=13.8,6.0)\end{array}$ & C-10a \\
\hline $4 a$ & 123.8 & - & & $10 \mathrm{a}$ & $\begin{array}{c}134 . \\
4\end{array}$ & - & \\
\hline $4 \mathrm{~b}$ & 135.1 & - & & 12 & $\begin{array}{c}167 . \\
9\end{array}$ & - & \\
\hline 5 & 127.7 & $\begin{array}{c}8.35(1 \mathrm{H}, d d \\
J=7.9,1.4)\end{array}$ & C-4a, C-4b & $3-\mathrm{OCH}_{3}$ & 59.7 & $3.89(3 \mathrm{H}, s)$ & $\mathrm{C}-3$ \\
\hline 6 & 127.9 & $\begin{array}{c}7.40(1 \mathrm{H}, d d \\
J=7.9,1.4)\end{array}$ & $\mathrm{C}-7$ & $4-\mathrm{OCH}_{3}$ & 56.0 & $4.00(3 \mathrm{H}, s)$ & $\mathrm{C}-4$ \\
\hline 7 & 130.0 & $\begin{array}{c}7.44(1 \mathrm{H}, d d \\
J=7.9,1.4)\end{array}$ & C-6, C-8a & $\mathrm{N}-\mathrm{OCH}_{3}$ & 63.7 & $3.96(3 \mathrm{H}, s)$ & \\
\hline 8 & 128.7 & $\begin{array}{c}7.35(1 \mathrm{H}, d d \\
J=7.9,1.4)\end{array}$ & $C-6, C-4 b$ & & & & \\
\hline
\end{tabular}

The ${ }^{1} \mathrm{H}-\mathrm{NMR}$ spectrum of 5 also showed signals at $\delta 2.73(\mathrm{H}-9 \alpha, t, J=13.8), \delta 3.49$ (H-9 $\beta, d d$, $J=14.2,6.0), \delta 4.60(\mathrm{H}-10, d d, J=13.8,6.0)$, indicating that $\mathrm{C}-9$ and $\mathrm{C}-10$ are hydrogenated. To the knowledge of the authors, this is the first occurrence of a 9,10-dihydroaristolactam alkaloid. The ${ }^{13} \mathrm{C}-\mathrm{NMR}$ spectrum (Table 4) showed the presence of eighteen carbons; three methyl, one methylene, six methine, seven quaternary and one carbonyl. The carbonyl carbon (C-12) resonated at $\delta$ 167.9. Thus, taking into consideration all the NMR data and analyses, the structure of tapisoidin (5) was elucidated as illustrated in Figure 1. Identification of the known compounds was done by comparison of ${ }^{1} \mathrm{H}$ - and ${ }^{13} \mathrm{C}-\mathrm{NMR}$ data with reported values [13-18].

\subsection{Bioactivity}

The result of cytotoxicity tests on the hexane, $\mathrm{CH}_{2} \mathrm{Cl}_{2}$ and $\mathrm{MeOH}$ crudes of $\mathrm{G}$. tapisoides against lung cancer (A549), breast cancer (MCF-7) and prostate cancer (DU-145) cell lines are shown in Table 5. Hexane and $\mathrm{CH}_{2} \mathrm{Cl}_{2}$ crude extracts exhibited cytotoxicity against the three cancer cell lines. 
Table 5. Cytotoxicity of crude extracts from G. tapisoides against selected cancer cells at $100 \mu \mathrm{g} / \mathrm{mL}$.

\begin{tabular}{cccc}
\hline \multirow{2}{*}{ Extracts } & \multicolumn{3}{c}{ Cell Viability (\%) } \\
\cline { 2 - 4 } & $\mathrm{A} 549$ & MCF-7 & DU-145 \\
\hline Hexane & 2.9 & 6.2 & 9.4 \\
$\mathrm{CH}_{2} \mathrm{Cl}_{2}$ & 2.9 & 6.4 & 8.3 \\
Methanol & 87.2 & 94.8 & 82.3 \\
\hline
\end{tabular}

Among the isolated compounds, compounds 1-6 were evaluated for their cytotoxicity (Table 6). Only compound 6 exhibited cytotoxic activity against all the eight cell lines. No cytotoxic activity was found for compounds 1-5, most probably due to lack of pharmacophoric groups responsible for the high antiproliferative activity [3].

Table 6. Biological activitiesof theisolated compounds $\left(\mathrm{IC}_{50}, \mu \mathrm{M}\right.$, mean \pm s.d., $\left.\mathrm{n}=3\right)$.

\begin{tabular}{|c|c|c|c|c|c|c|c|c|c|}
\hline \multirow[b]{2}{*}{ Cmpd. } & \multirow{2}{*}{$\begin{array}{c}\text { Antioxidant } \\
\text { activity }\end{array}$} & \multicolumn{8}{|c|}{ Cytotoxicity } \\
\hline & & $\mathrm{A}^{2} 49^{1}$ & DU-145 ${ }^{2}$ & $\begin{array}{c}\text { SK- } \\
\text { MEL-5 }^{3}\end{array}$ & BxPC- $3^{4}$ & Hep $\mathbf{~} 2^{5}$ & HT-29 ${ }^{6}$ & MCF- $7^{7}$ & $\begin{array}{c}\text { MDA- } \\
\text { MB-231 }^{8}\end{array}$ \\
\hline 1 & 0.328 & $>150$ & $>150$ & $>150$ & $>150$ & $>150$ & $>150$ & $>150$ & $>150$ \\
\hline 2 & 0.207 & $>150$ & $>150$ & $>150$ & $>150$ & $>150$ & $>150$ & $>150$ & $>150$ \\
\hline 3 & 1.748 & $>150$ & $>150$ & $>150$ & $>150$ & $>150$ & $>150$ & $>150$ & $>150$ \\
\hline 4 & 0.252 & $>150$ & $>150$ & $>150$ & $>150$ & $>150$ & $>150$ & $>150$ & $>150$ \\
\hline 5 & 0.772 & $>150$ & $>150$ & $>150$ & $>150$ & $>150$ & $>150$ & $>150$ & $>150$ \\
\hline 6 & 2.024 & $\begin{array}{l}107.62 \\
\pm 4.67\end{array}$ & $\begin{array}{r}71.79 \\
\pm 1.61\end{array}$ & $\begin{array}{c}100.14 \\
\pm 11.84\end{array}$ & $\begin{array}{l}130.48 \\
\pm 7.69\end{array}$ & $\begin{array}{l}128.73 \\
\pm 1.81\end{array}$ & $\begin{array}{c}64.17 \\
\pm 5.60\end{array}$ & $\begin{array}{c}120.37 \\
\pm 11.11\end{array}$ & $>150$ \\
\hline Cisplatin & - & $\begin{array}{c}37.37 \\
\pm 3.00\end{array}$ & $\begin{array}{c}15.18 \\
\pm 0.49\end{array}$ & $\begin{array}{l}31.82 \\
\pm 0.23\end{array}$ & $\begin{array}{l}20.10 \\
\pm 1.21\end{array}$ & $\begin{array}{l}22.07 \\
\pm 0.64\end{array}$ & $\begin{array}{c}77.24 \\
\pm 3.23\end{array}$ & $\begin{array}{l}91.49 \\
\pm 6.54\end{array}$ & $\begin{array}{l}276.53 \\
\pm 1.29\end{array}$ \\
\hline $\begin{array}{c}\text { Ascorbic } \\
\text { acid }\end{array}$ & 0.075 & - & - & - & - & - & - & - & - \\
\hline
\end{tabular}

${ }^{1}$ human lung carcinoma; ${ }^{2}$ human prostate carcinoma; ${ }^{3}$ skin cancer cell line; ${ }^{4}$ human pancreatic carcinoma;

${ }^{5}$ human liver carcinoma; ${ }^{6}$ human colon carcinoma; ${ }^{7,8}$ human breast carcinomas.

Compound 6 is the most potent against the colon cancer cell line (HT-29). It exhibited an $\mathrm{IC}_{50}$ of $64.17 \pm 5.60 \mu \mathrm{M}$, which is comparable to that of cisplatin $(77.24 \pm 3.23 \mu \mathrm{M})$. Therefore the cytotoxicity of both hexane and dichloromethane extracts may be attributed to the presence of compound 6, which has been previously reported to exhibit cytotoxicity against various cancer cell lines $[13,19]$. In addition, reports have shown that the antiproliferative activity of $\mathbf{6}$ is selective for cancer cell lines with no significant cytotoxicity toward non-malignant cells $[13,20]$.

Since free radicals are associated with DNA damage and protein modifications, including apoptotic modulators which could lead to carcinogenesis [21], we have also evaluated the antioxidant activity using a DPPH radical scavenging assay. Compound $\mathbf{2}$ gave the highest antioxidant activity, with an $\mathrm{IC}_{50}$ of $0.207 \mu \mathrm{M}$, followed by compounds $4\left(\mathrm{IC}_{50}=0.252 \mu \mathrm{M}\right)$ and $\mathbf{1}\left(\mathrm{IC}_{50}=0.328 \mu \mathrm{M}\right)$. The high antioxidant effect of compounds 2, 4 and $\mathbf{1}$ may be attributed to the presence of the hydroxyl group adjacent to the conjugated double bond that could donate electron to the DPPH free radical. Carotenes and xanthophyll which possess hydroxyl groups and conjugated double bonds have been reported to 
show high antioxidant activity [22,23]. Compounds $3\left(\mathrm{IC}_{50}=1.748 \mu \mathrm{M}\right), \mathbf{5}\left(\mathrm{IC}_{50}=0.772 \mu \mathrm{M}\right)$ and $\mathbf{6}$ $\left(\mathrm{IC}_{50}=2.024 \mu \mathrm{M}\right)$ which lack hydroxyl groups in their structures showed very low antioxidant activity.

\section{Experimental}

\subsection{General}

Melting points were determined by a Fargo MD-1D melting point apparatus. The specific rotations were measured on a Jasco P-1020 polarimeter. UV spectra were recorded on a Shimadzu 1650 PC ultraviolet-visible spectrometer, and IR spectra on a Perkin Elmer Spectrum 400 FT-IR/FT-FIR spectrometer. 1D and 2D NMR spectra were measured with a JEOL ECA 400 spectrometer (400 MHz). The mass spectra were obtained on an Agilent Technologies 6530 Accurate-Mass-Q-TOF LC/MS. Column chromatography was performed on silica gel Merck 60 (230-400 mesh). X-ray data collection was obtained from a Bruker APEX2 unit; cell refinement: SMART; data reduction: SAINT; program(s) used to solve the structure: SHELXTL; program(s) used to refine structure: SHELXTL.

\subsection{Plant Material}

The stem bark of G. tapisoides was collected from Sarawak and identified by Prof. Fasihuddin bin Ahmad, Faculty of Resource Science and Technology, Universiti Malaysia Sarawak. A voucher specimen (HUMS 000108) is deposited at the Herbarium of Universiti Malaysia Sarawak, Kota Samarahan, Sarawak, Malaysia.

\subsection{Extraction and Isolation}

The dried and milled stem barks of $G$. tapisoides $(1.5 \mathrm{~kg})$ were extracted successively with hexane, dichloromethane $\left(\mathrm{CH}_{2} \mathrm{Cl}_{2}\right)$ and $\mathrm{MeOH}(15 \mathrm{~L})$ to give $25 \mathrm{~g}$ of hexane extract, $43 \mathrm{~g}$ of $\mathrm{CH}_{2} \mathrm{Cl}_{2}$ extract and $24 \mathrm{~g}$ of $\mathrm{MeOH}$ extract, respectively, after removal of the solvents. The hexane extract $(10 \mathrm{~g})$ was subjected to silica gel column chromatography (CC), using hexane and $\mathrm{CH}_{2} \mathrm{Cl}_{2}$ with increasing polarity to give $6(2.5 \mathrm{~g})$. Then, the $\mathrm{CH}_{2} \mathrm{Cl}_{2}$ extract $(20 \mathrm{~g})$ was fractionated using $\mathrm{CC}$ with a gradient system of hexane/ $\mathrm{CH}_{2} \mathrm{Cl}_{2}$ and $\mathrm{CH}_{2} \mathrm{Cl}_{2} / \mathrm{MeOH}$ to afford 11 fractions (F1-F11). F8 $\left(\mathrm{CH}_{2} \mathrm{Cl}_{2} / \mathrm{MeOH}\right.$, 90:10) was separated on a column of silica gel using $\mathrm{CH}_{2} \mathrm{Cl}_{2} / \mathrm{MeOH}(97: 3)$ as the eluent to give 1 (12.3 mg). F9 $\left(\mathrm{CH}_{2} \mathrm{Cl}_{2} / \mathrm{MeOH}, 80: 20\right)$ was further chromatographed on a silica gel column eluting with $100 \% \mathrm{CH}_{2} \mathrm{Cl}_{2}$ to give 2. F10 $\left(\mathrm{CH}_{2} \mathrm{Cl}_{2} / \mathrm{MeOH}, 50: 50\right)$ was then purified by $\mathrm{CC}$, using $\mathrm{CH}_{2} \mathrm{Cl}_{2} / \mathrm{MeOH}$ (99:1) to yield 3 (14.8 mg) and $\mathrm{CH}_{2} \mathrm{Cl}_{2} / \mathrm{MeOH}$ (96:4) to yield 4 (18.9 mg). $\mathrm{F} 6\left(\mathrm{CH}_{2} \mathrm{Cl}_{2} / \mathrm{MeOH}, 98: 2\right)$ was applied to a column of silica gel, eluted with $\mathrm{CH}_{2} \mathrm{Cl}_{2} / \mathrm{MeOH}$ (98:2) gave 5 (3.2 mg). F3 ( $\left.\mathrm{Hex} / \mathrm{CH}_{2} \mathrm{Cl}_{2}, 50: 50\right)$ was further purified by silica gel $\mathrm{CC}$ using hexane/ $\mathrm{CH}_{2} \mathrm{Cl}_{2}$ (50:50) as eluting solvent to afford $6(1.3 \mathrm{~g})$. F6 was subjected to silica gel $\mathrm{CC}$, using $100 \% \mathrm{CH}_{2} \mathrm{Cl}_{2}$ as eluent to yield 7 (4.8 mg). F7 $\left(\mathrm{CH}_{2} \mathrm{Cl}_{2} / \mathrm{MeOH}, 95: 5\right)$ was separated on column of silica gel using $\mathrm{CH}_{2} \mathrm{Cl}_{2} / \mathrm{MeOH}$ (95:5) as developing solvent to yield $\mathbf{8}(1.1 \mathrm{~g})$. Compounds $\mathbf{9}(1.2 \mathrm{mg}), \mathbf{1 0}(4.4 \mathrm{mg})$ and $\mathbf{1 1}(4.0 \mathrm{mg})$ were obtained from further purification of $\mathrm{F} 6\left(\mathrm{CH}_{2} \mathrm{Cl}_{2} / \mathrm{MeOH}, 98: 2\right)$ by $\mathrm{CC}$ using silica gel with a solvent system of $\mathrm{CH}_{2} \mathrm{Cl}_{2} / \mathrm{MeOH}(98: 2)$. 


\subsection{Cytotoxicity Assay}

Cytotoxicity of the compounds were evaluated against eight types of cancer cell lines; lung (A549), prostate (DU-145), skin (SK-MEL-5), pancreatic (BxPC-3), liver (Hep G2), colon (HT-29), breast cancer (MCF-7), and (MDA-MB-231). Cell lines were cultured in Dulbecco's Modified Eagle medium (DMEM) with 10\% foetal bovine serum. Cells were plated into 96-well microplates and 24 hour later, $100 \mu \mathrm{L}$ of samples and cisplatin standard were introduced in triplicate. Cells were further incubated for $48 \mathrm{~h}$ and cell viability was determined using the MTS reagent (Promega Corp., Madison, WI, USA). Microplates were returned to the incubator for $1 \mathrm{~h}$ and absorbance was read on a microplate reader at $490 \mathrm{~nm}$ (Infinite 200, Tecan, Männedorf, Swizerland). The concentration required causing 50\% cell death $\left(\mathrm{IC}_{50}\right)$ by the samples and drug standards were determined using dose-response curves in Prism 5.02 software [24].

\subsection{Antioxidant Assay}

The DPPH antioxidant assay was determined as described by Shimada et al. [25]. Briefly, $0.1 \mathrm{mM}$ DPPH (1 mL) dissolved in ethanol was added to an ethanol solution $(3 \mathrm{~mL})$ of the tested compound at different concentrations $(0,50,100,150,200 \mu \mathrm{g} / \mathrm{mL})$. An equal volume of ethanol was added in the control test. The mixture was shaken vigorously and allowed to stand at room temperature for $30 \mathrm{~min}$. Then the absorbance at $517 \mathrm{~nm}$ was measured with a UV-VIS spectrophotometer. The percentage of scavenging of DPPH was calculated using the following equation:

$$
\text { DPPH scavenging effect }(\%)=\frac{A^{\circ}-A 1}{A^{\circ}} \times 100
$$

where $\mathrm{A}^{\mathrm{o}}$ is the absorbance of the control reaction and $\mathrm{A} 1$ is the absorbance in the presence of the sample.

\section{Conclusions}

The $\mathrm{CH}_{2} \mathrm{Cl}_{2}$ extract of the stem bark of $G$. tapisoides yielded eleven compounds, of which five are new; goniomicins A-D (compounds 1-4), and tapisoidin (5). The latter, tapisoidin (5), represents the first report of the occurence of a 9,10-dihydroaristolactam alkaloid. From this study, the compound responsible for the cytotoxicity of the extracts is goniothalamin (6), which showed the highest potency against the colon cancer cell line (HT-29) withan $\mathrm{IC}_{50}$ of $64.17 \pm 5.60 \mu \mathrm{M}$. Goniomicin A (1), goniomicin B (2) and goniomicin D (4) displayed high antioxidant activity, which may be due to the presence of conjugated hydroxyl groups that could donate electrons to scavenge radicals $[22,23]$.

\section{Supplementary Materials}

Supplementary materials can be accessed at: http://www.mdpi.com/1420-3049/18/1/128/s1.

\section{Acknowledgments}

This work was supported by grant from the Institute of Research Management and Monitoring (IPPP) of University Malaya (No. PS339/2010A), FRGS of University Teknologi Mara 
(600-RMI/ST/FRGS5/3/Fst(135/2010)), 02(DPI02)/792/2011(02) of UNIMAS， UMRG Program (RP001/2012A) and (RP001/2012B).

\section{References}

1. Wiart, C. Goniothalamus species: A source of drugs for the treatment of cancers and bacterial infections? Evid. Based Complement. Alternat. Med. 2007, 4, 299-311.

2. Ahmad, F.; Moharm, B.A.; Jantan, I. A comparative study of the constituents of the essential oils of Goniothalamus tapis Miq. and G. tapisoides Mat Salleh from Borneo. J. Essent. Oil Res. 2010, 22, 499-502.

3. Fátima, Â.; Modolo, L.V.; Conegero, L.S.; Pilli, R.A.; Ferreira, L.K.; Kohn, L.K.; Carvalho, J.E. Styryl lactones and their derivatives: Biological activities, mechanisms of action and potential leads for drug design. Curr. Med. Chem. 2006, 13, 3371-3384.

4. Inayat-Hussain, S.H.; Osman, A.B.; Din, L.B.; Ali, A.M.; Snowden, R.T.; MacFarlane, M.; Cain, K. Caspases-3 and -7 are activated in goniothalamin-induced apoptosis in human Jurkat T-cells. FEBS Lett. 1999, 456, 379-383.

5. Lee, A.T.C.; Azimahtol, H.L.P.; Tan, A.N. Strylpyrone Derivative (SPD) induces apoptosis in a capase-7-dependent manner in the human breast cancer cell line MCF-7. Cancer Cell Int. 2003, 3, $16-23$.

6. Inayat-Hussain, S.H.; Osman, A.B.; Din, L.B.; Ali, A.M.; Ross, D. Loss of mitochondrial transmembrane potential and caspase-9 activation during apoptosis induced by the novel styryl-lactone goniothalamin in HL-60 leukemia cells. Toxicol. In Vitro 2003, 17, 433-439.

7. Litaudon, M.; Guéritte, F.; Bousserouel, H.; Awang, K.; Nosjean, O.; Martin, M.T.; Tran Huu Dau, M.E.; Sévenet, T. A dimeric sesquiterpenoid from a Malaysian Meiogyne as a new inhibitor of Bcl-xL/BakBH3 domain peptide interaction. J. Nat. Prod. 2009, 72, 480-483.

8. Mohamad, K.; Hirasawa, Y.; Litaudon, M.; Awang, K.; Hadi, A.H.A.; Takeya, K.; Ekasari, W.; Morita, H. Ceramicines B-D, new antiplasmodial limonoids from Chisocheton ceramicus. Bioorg. Med. Chem. 2009, 17, 727-730.

9. Mohamad, K.; Hirasawa, Y.; Lim, C.S.; Awang, K.; Hadi, A.H.A.; Takeya, K.; Morita, H. Ceramicine A and walsogyne A, novel limonoids from two species of Meliaceae. Tetrahedron Lett. 2008, 49, 4276-4278.

10. Mukhtar, M.R.; Martin, M.T.; Domansky, M.; Pais, M.; Hadi, A.H.A.; Awang, K. Phoebegrandines $\mathrm{A}$ and $\mathrm{B}$, proaporphine-tryptamine dimmers, from Phoebe grandis. Phytochemistry 1997, 45, 1543-1546.

11. Anderson, R.J.; Bendell, D.J.; Groundwater, P.W. Organic Spectroscopic Analysis; Royal Society of Chemistry: Cambridge, UK, 2004, pp. 13-80.

12. Desai, S.J.; Charturvedi, R.N.; Badheka, L.P.; Mulchandani, N.P. Aristolactams and 4,5 dioxoaporphines from Indian PIPER species. Indian J. Chem. 1989, 28, 775-777.

13. Fátima, Â.; Kohn, L.K.; Antônio, M.A.; Carvalho, J.E.; Pilli, R.A. (R)-Goniothalamin: Total syntheses and cytotoxic activity against cancer cell lines. Bioorg. Med. Chem. 2005, 13, 2927-2933. 
14. Tai, B.H.; HuYen, V.T.; Huong, T.T.; Nhiem, N.X.; Choi, E.M. New prano-pyrone from Goniothalamus tamirensis Enchances the Proliferation and Differentiation of Osteoblastic MC3T3-E1 Cells. Chem. Pharm. Bull. 2010, 58, 521-525.

15. Zhu, W.M.; Zhao, Q.; Li, S.L.; Hao, X.J. Sesquiterpenoids from Hedychium yunnanense and Porana discifera, and the structural revision of two sesquiterpenoids from Laggera pterodonta. J. Asian Nat. Prod. Res. 2007, 9, 277-283.

16. Bick, I.R.C.; Douglas, G.K. Yellow alkaloids of Atherosperma moschatum. Tetrahedron Lett. 1964, 25, 1629-1633.

17. Aires-de-Sousa, J.; Hemmer, M.C.; Gasteiger, J. Prediction of ${ }^{1}$ H-NMR chemical shifts using nueral networks. Anal. Chem. 2002, 74, 80-90.

18. Hanai, K.; Kuwae, A.; Takai, T.; Senda, H.; Kunimoto, K. A comparative vibrational and NMR study of cis-cinnamic acid polymorphs and trans-cinnamic acid. Spectrochim. Acta A 2001, 57, 513-519.

19. Wattanapiromsakul, C.; Wangsintaweekul, B.; Sangprapan, P.; Itharat, A.; Keawpradub, N. Goniothalamin, a cytotoxic compound, isolated from Goniothalamus macrophyllus (Blume) Hook. f. \& Thomson var. macrophyllus. Songklanakarin J. Sci. Technol. 2005, 27, 479-487.

20. Pihie, A.H.L.; Stanslas, J.; Bin, D.L. Non-steroid receptor-mediated antiproliferative activity of styrylpyrone derivative in human breast cancer cell lines. Anticancer Res.1998, 18, 1739-1744.

21. Hussain, S.P.; Hofseth, L.J.; Harris C.C.M. Radical causes of cancer. Nat. Rev. Cancer 2003, 3, 276-285.

22. Miller, N.J.; Sampson, J.; Candeias, L.P.; Bramley, P.M.; Rice-Evans, C.A. Antioxidant activities ofcarotenes and xanthophylls. FEBS Lett. 1996, 384, 240-242.

23. Tian, B.; Xu, Z.; Sun, Z.; Lin, J.; Hua, Y. Evaluation of the antioxidant effects of carotenoids from Deinococcus radiodurans through targeted mutagenesis, chemiluminescence, and DNA damage analyses. Biochim. Biophys. Acta 2007, 1770, 902-911.

24. Prism, 5.0 software; GraphPad Software Inc.: La Jolla, CA, USA, 2009.

25. Shimada, K.; Fujikawa, K.; Yahara, K.; Nakamura, T. Antioxidative properties of xanthin onautoxidation of soybean oil in cyclodextrin emulsion. J. Agric. Food Chem. 1992, 40, 945-948.

Sample Availability: Samples of the compounds are available from the authors.

(C) 2013 by the authors; licensee MDPI, Basel, Switzerland. This article is an open access article distributed under the terms and conditions of the Creative Commons Attribution license (http://creativecommons.org/licenses/by/3.0/). 